by Guifang Yang ${ }^{a}$, Zhenghong Chen $^{b}$, Fadong Wu ${ }^{a}$, Mingzhong Tian ${ }^{a}$, Yali Li $^{a}$

\title{
Fuzzy multiattribute assessment of geoscience popularization in the Global Geoparks of China
}

\author{
${ }^{a}$ School of Earth Sciences and Resources, China University of Geosciences, Beijing 100083, China. E-mail: yangcugb@gmail.com
} ${ }^{\mathrm{b}}$ China Meteorological Administration Training Centre, Beijing 100081, China. E-mail: chenzhengh@cma.gov.cn

Inherent uncertainties in the range of hardware (or the physical parts or components of geoscience popularization within geoparks, including basic infrastructure and museums) and software (or associated interpretation service system and publicity style) conditions that affect geoscience popularization present major challenges for geopark management and regional development. Selecting an appropriate geoscience popularization assessment method is essential for the success of geopark planning and construction. This study uses a fuzzy multiattribute approach to deal with the imprecision inherent to the process of subjective judgment and rank the popularization performance for 27 global geoparks in China. The performance ranking is based on the closeness coefficients for alternatives, which is calculated using the distances of alternatives from the fuzzy positive ideal and fuzzy negative ideal solutions. Results of the multiattribute method are consistent with those of a synthetic index method and other procedures. Hardware and software conditions are the key determinants of geoscience popularization. Human quality and management level slightly adjust the overall popularization performance of geoparks. Results of the study provide a significant basis for geo-resource conservation and geoscience popularization, aiding efforts to support the sustainable development of the geoparks.

\section{Introduction}

The public awareness of geoscience popularization has been largely enhanced by the global geopark network (GGN). Geoparks are defined as an innovation for the protection of natural and geological heritages and communication of geoscience knowledge, playing an important role within the development of local sustainable economy (Eder and Patzak, 2004; Yang et al., 2011). In parallel to the work of geoscientists in other countries, the geoscience community of China attaches great importance to the conservation of geosites, dedicating to the goal of scientific protection and sustainable development. The result of these efforts over the past decades has been the initiation of
27 Global Geoparks (or World Geoparks) and 219 National Geoparks (Yang et al., 2013). In spite of these progresses, during recent years some geoscience popularization patterns of many geoparks within China remain poorly documented in the international literature (Zhao and Wang, 2002; Yang et al., 2011, 2013). Reasonable assessment of geoscience popularization and establishment of effective geoconservation strategies have been the critical challenge in the design of geopark plans.

More recently, concerns for the effective assessment of geoscience popularization within geoparks around the world have been increasingly linked to questions of regional socio-economic development, and long-term geopark management (e.g. Eder and Patzak, 2004; UNESCO, 2008). Systematic appraisal of geoscience popularization relative to economic development and geoheritage protection is a critical first step in the evaluation of geopark function (Yang et al., 2013). Various approaches to geodiversity identification and analysis of geo-education pattern have been developed for geoparks using multiple attribute and subjective assessments (Zouros and Valiakos, 2010; Comãnescu and Nedelea, 2012). Despite these developments, the complex interaction of multiple parameters and inherent uncertainty have limited the successful development and application of procedures to assess geoscience popularization performance (Serrano and Ruiz Flano, 2007).

The aim of this contribution is to characterize the behavior of geoscience popularization as a strategy for both geoconservation and regional development within global geoparks in China. Multiattribute analysis and fuzzy set theory are used to represent the multidimensional nature of geoscience popularization patterns. The approach developed here reduces subjectivity and imprecision in the decision-making processes, aiding the identification of countermeasures with which to alleviate geoscience popularization vulnerability, thereby enhancing prospects for the development of more strategic approaches to geopark management in China.

\section{Database setting}

China so far has 27 global geopark network members, accounting for nearly $30 \%$ of those all over the world. These geoparks in China annually attract hundreds of millions of tourists, and have also accumulated lots of experience in terms of geopark construction and regional development.

A total of 27 global geoparks was chosen for this study, as indicated on Fig 1. Yearly reports of various geoparks were recorded in various references and reports (Chen, 2002, 2003; Qian and Zhao, 2004; Qian and Ling, 2005; Wu and Fu, 2009; Huang and Yang, 2011; Yang et al., 2013). Reference reorganization, field investigations, 


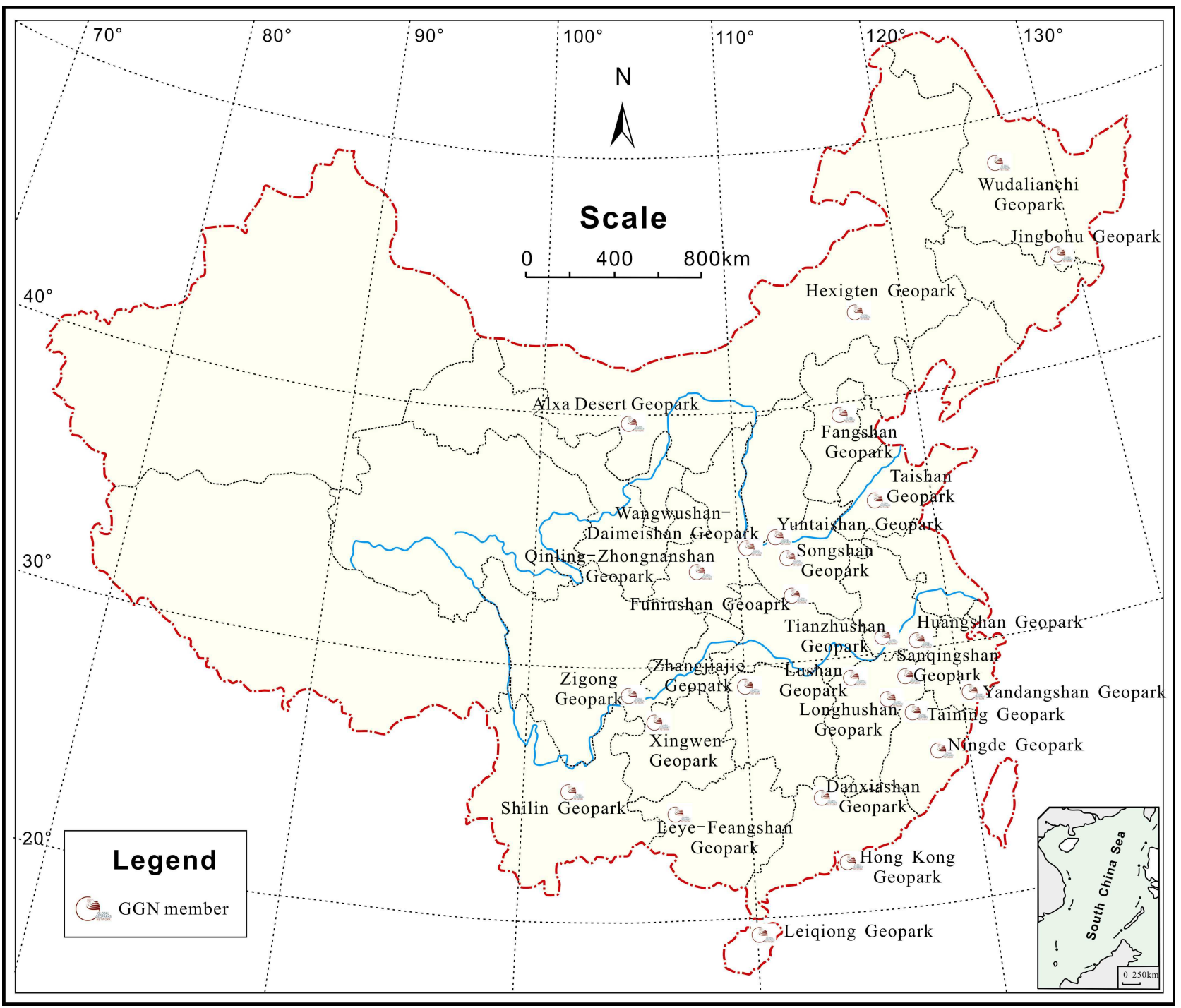

Figure 1. Geographical location of the global geoparks in China

expert interview, and questionnaire survey were incorporated into our present studies to characterize the global geoparks in China (Yang et al., 2013).

\section{Methods and problem formulation}

\section{Description of methodology}

The fuzzy multiattribute method used here is a widely accepted approach to multiattribute analysis decision making in real-world settings (Chen and Klein, 1997; Rashed and Weeks, 2003). In many instances ratings and weights of criteria given as crisp values are inadequate in modeling real-life conditions (Chen, 2000), as the geoscience popularization is characterized by vague boundaries for grading. Such an assessment of geoscience popularization is a multiple attribute analysis process due to involvement of several decision criteria. The required information in such a process is not always precisely defined. In this sense, the fuzzy multiattribute analysis is well suited to evaluate the performance of the available geoparks to geoscience popularization pattern. We used the fuzzy multiattribute assessment method defined by Deng and Yang (2005). A closeness coefficient was defined as the distance between each alternative and the fuzzy positive/negative ideal solution $\left(d_{\mathrm{i}}^{+} / d_{\mathrm{i}}^{-}\right.$, referring to Deng and Yang, 2005):

$$
P_{i=} \frac{d_{i}^{-}}{d_{i}^{+}+d_{i}^{-}} i=1,2, \ldots, n
$$

Here the closeness coefficient is between zero and one. As the closeness coefficient approaches 1 , the attributes for that alternative approach the attributes for the fuzzy positive-ideal solution and depart from the attributes for the fuzzy negative-ideal solution. Therefore, the closer the closeness coefficient is to one, the more preferred the alternative.

\section{Formulation of vulnerability assessment}

An overall evaluation of available alternative segments with respect to various attributes is required to effectively prioritize the geoscience popularization performance to geoparks. After comprehensive consultations with a large numbers of stakeholders, software condition $\left(C_{1}\right)$, hardware characteristics $\left(C_{2}\right)$, and human 


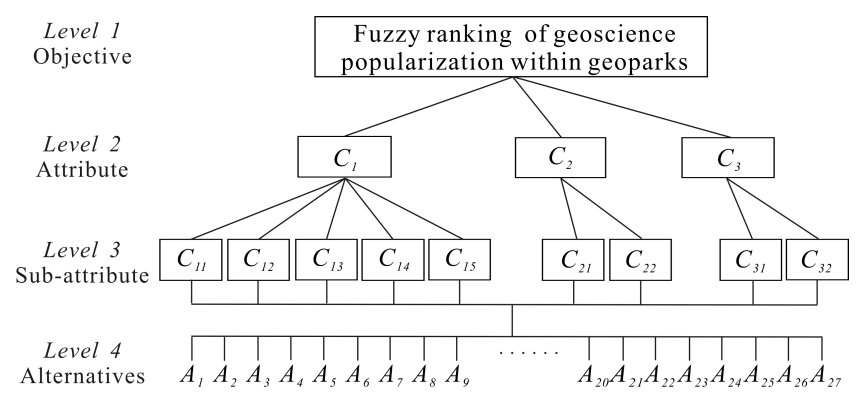

Figure 2. The hierarchical structure of the evaluation problem

impact $\left(C_{3}\right)$ were selected as three major attributes for evaluating the geoscience popularization vulnerability of global geoparks in China. The hierarchical structure of the evaluation problem is schematically illustrated in Fig. 2. The software condition $\left(C_{l}\right)$ indicates associated interpretation service system and publicity style. It essentially reflects the potential level of geoscience education. Components such as interpretation system $\left(C_{11}\right)$, distinctive products $\left(C_{12}\right)$, popularization way $\left(C_{13}\right)$, unique geoscience routes $\left(C_{14}\right)$ and in-depth scientific research $\left(C_{15}\right)$ can improve the interpretive assistance or instruction made available to visitors of the geopark. Hence, it is crucial to assess the likelihood and intensity of scientific knowledge in order to develop appropriate geopark management and loss mitigation strategies. The hardware characteristic $\left(C_{2}\right)$ refers to the physical parts or components of geoscience popularization within geoparks. It is an indication of the extent to which the potential popularization activities or products are present $\left(C_{21}\right)$ and the associated basic construction can occur $\left(C_{22}\right)$. The human impact $\left(C_{3}\right)$ reflects the ability to implement geoscience popularization activities or their impacts upon the occurrence of geoscience popularization in the given region. This is closely associated with professional qualification $\left(C_{31}\right)$ and underlying enthusiasm $\left(C_{32}\right)$.

These above mentioned attributes and their associated subattributes will, to a certain degree, alter the pattern of the geoscience popularization, showing a positive contribution to science education level with a relatively higher interpretive assistance or instruction. Obviously, the ranges of software and hardware construction are the primary determinants of geoscience popularization level. Considering the overall geoscience popularization level and relatively evenly professional quality, human factors play a secondary role in geoscience education within geoparks.

\section{Results}

Subjective assessments of the weights for the three attributes and their associated sub-attributes and the vulnerability of each geopark with regard to each sub-attribute based on the linguistic terms defined in Tables 1 and 2 are presented in Table 3. Table 4 presents the fuzzy weights for the attributes and sub-attributes. In general, the higher closeness coefficient, the higher geoscience popularization level is. Therefore, the different grades for each attributes and their associated sub-attributes can be assigned different values (Tables 3 and 4). Based on these above-mentioned procedures and associated values given in Table 1 to 4, we can calculate the decision matrix. Multiplying the decision matrix with the weighting vector, the weighted fuzzy matrix of all the alternatives can be obtained.

The distances between each alternative and fuzzy positive ideal solution and negative ideal solution are computed, respectively and
Table 1. Linguistic variables used to describe the effects of alternatives on attributes

\begin{tabular}{lccccc}
\hline Linguistic Variables & $\begin{array}{c}\text { Very Low } \\
(\mathrm{VL})\end{array}$ & $\begin{array}{c}\text { Low } \\
(\mathrm{L})\end{array}$ & $\begin{array}{c}\text { Fair } \\
(\mathrm{F})\end{array}$ & $\begin{array}{c}\text { High } \\
(\mathrm{H})\end{array}$ & $\begin{array}{c}\text { Very High } \\
(\mathrm{VH})\end{array}$ \\
Fuzzy Numbers & $(1,1,3)$ & $(1,3,5)$ & $(3,5,7)$ & $(5,7,9)$ & $(7,9,9)$ \\
\hline
\end{tabular}

Table 2 Linguistic terms used by the weighting vectors

\begin{tabular}{lccccc}
\hline $\begin{array}{l}\text { Linguistic } \\
\text { Variables }\end{array}$ & $\begin{array}{c}\text { Least } \\
\text { Important }\end{array}$ & $\begin{array}{c}\text { Less } \\
\text { Important }\end{array}$ & Important & $\begin{array}{c}\text { More } \\
\text { Important }\end{array}$ & $\begin{array}{c}\text { Most } \\
\text { Important }\end{array}$ \\
Fuzzy Numbers & $(1,1,3)$ & $(1,3,5)$ & $(3,5,7)$ & $(5,7,9)$ & $(7,9,9)$ \\
\hline
\end{tabular}

the closeness coefficients are calculated. The 27 geoparks ranked for popularization vulnerability based on their closeness coefficients (Table 5). The vulnerability of global geoparks is classified as very good, good, medium, bad, or worse with 5 grades (very low, low, fair, high and very high with a value of $<0.25,0.25 \sim 0.35,0.35 \sim 0.40$, $0.40 \sim 0.45,>045$ respectively). To facilitate a comparative study, Table 5 also shows the assessment results from a synthetic index analysis (SIA, Yang et al., 2013).

In general terms, the ranking of alternatives based on the fuzzy multiattribute approach is consistent with the ranking based on the synthetic index (Table 5 and Fig. 3). Approximately $70 \%$ of all 27 geoparks have very low or low geoscience popularization vulnerability, usually showing poor geoscience popularization conditions (as indicated as red and yellow colors in Fig. 3(A)). In contrast, geoparks from northeast and southwest China have medium to high geoscience popularization levels as shown in green and light blue colors (Fig. 3(A)). Despite the good correlation between the two methods, some local discrepancies are evident. For instance, the previous comprehensive index analysis indicates that the geoscience popularization vulnerability of Ningde Geopark is featured by very low geoscience popularization level as indicated in red in Fig. 3(B), whereas the fuzzy multiattribute assessment presented here classified this geopark as having low geoscience popularization level (Fig.3A).

\section{Discussion}

\section{Advantages of method}

The fuzzy multiattribute evaluation method applied here is a creative and comprehensive way to use fuzzy decision-making in geoscience popularization pattern assessment. The similarity in the ranking of alternatives for different geoparks obtained with synthetic index analysis and fuzzy multiattribute method indicates that the latter can yield a rational evaluation, which can be compared and combined with other procedures (Chen, 2003; Deng and Yang, 2005; Huang and Yang, 2011; Yang et al., 2013). The fuzzy multiattribute estimation method application provides a visual indication of the variation in the intensity of the considered attributes, thereby providing meaningful and usable assessments of geoscience popularization performance. The method is especially useful when there are poorly-defined grading boundaries and/or limited data. As such, the proposed methodology uses the linguistic assessments instead of numerical values, enriching theoretical understanding of geoscience popularization patterns of the study area. To guarantee the performance of the fuzzy assessment method, the method was also evaluated by a large number of geoscience popularization experts from different geoparks for various criteria such as applicability, similarity, efficiency, and the overall 
Table 3 Fuzzy grading of the attribute, sub-attribute and their weights

\begin{tabular}{|c|c|c|c|c|c|}
\hline Attribute & Weight & Sub-attribute & Weight & Grading principle & Categories \\
\hline \multirow{4}{*}{$\begin{array}{l}\text { Software } \\
\text { condition }\left(C_{1}\right)\end{array}$} & \multirow{4}{*}{$\begin{array}{c}\mathrm{VH} \\
(7,9,9)\end{array}$} & $\begin{array}{l}\text { Interpretation } \\
\text { system }\end{array}$ & $\begin{array}{c}V H \\
(7,9,9)\end{array}$ & $\begin{array}{l}\text { Comprehensive } \\
\text { Relatively complete } \\
\text { General } \\
\text { Poor } \\
\text { Little or none }\end{array}$ & $\begin{array}{l}\mathrm{VH} \\
\mathrm{H} \\
\mathrm{F} \\
\mathrm{L} \\
\mathrm{VL}\end{array}$ \\
\hline & & $\begin{array}{l}\text { Distinctive } \\
\text { products }\end{array}$ & $\begin{array}{c}\mathrm{H} \\
(5,7,9)\end{array}$ & $\begin{array}{l}\text { Typical } \\
\text { Better } \\
\text { Fair } \\
\text { Poor } \\
\text { Little or none }\end{array}$ & $\begin{array}{c}\mathrm{VH} \\
\mathrm{H} \\
\mathrm{F} \\
\mathrm{L} \\
\mathrm{VL}\end{array}$ \\
\hline & & $\begin{array}{l}\text { Popularization } \\
\text { way }\end{array}$ & $\begin{array}{c}\text { VH } \\
(7,9,9)\end{array}$ & $\begin{array}{l}\text { Best } \\
\text { Good } \\
\text { General } \\
\text { Poor } \\
\text { Little or none } \\
\end{array}$ & $\begin{array}{l}\mathrm{VH} \\
\mathrm{H} \\
\mathrm{F} \\
\mathrm{L} \\
\mathrm{VL}\end{array}$ \\
\hline & & $\begin{array}{l}\text { Unique geoscience } \\
\text { routes and activities }\end{array}$ & $\begin{array}{c}F \\
(3,5,7)\end{array}$ & $\begin{array}{l}\text { Perfect } \\
\text { Good } \\
\text { General } \\
\text { Poor } \\
\text { Little or none }\end{array}$ & $\begin{array}{c}\mathrm{VH} \\
\mathrm{H} \\
\mathrm{F} \\
\mathrm{L} \\
\mathrm{VL}\end{array}$ \\
\hline \multirow{3}{*}{$\begin{array}{l}\text { Hardware } \\
\text { characteristic }\left(C_{2}\right)\end{array}$} & \multirow{3}{*}{$\begin{array}{c}\mathrm{F} \\
(3,5,7)\end{array}$} & $\begin{array}{l}\text { In-depth } \\
\text { scientific } \\
\text { research }\end{array}$ & $\begin{array}{c}\mathrm{F} \\
(3,5,7)\end{array}$ & $\begin{array}{l}\text { Thorough } \\
\text { Better } \\
\text { Moderate } \\
\text { Slight } \\
\text { Little or none }\end{array}$ & $\begin{array}{c}\text { VH } \\
\mathrm{H} \\
\mathrm{F} \\
\mathrm{L} \\
\mathrm{VL}\end{array}$ \\
\hline & & $\begin{array}{l}\text { Geomuseum or } \\
\text { poplarization } \\
\text { centre }\end{array}$ & $\begin{array}{c}\mathrm{H} \\
(5,7,9)\end{array}$ & $\begin{array}{l}\text { Perfect } \\
\text { Relatively perfect } \\
\text { Fundamental } \\
\text { Poor } \\
\text { Little or none } \\
\end{array}$ & $\begin{array}{c}\mathrm{VH} \\
\mathrm{H} \\
\mathrm{F} \\
\mathrm{L} \\
\mathrm{VL}\end{array}$ \\
\hline & & $\begin{array}{l}\text { Associated basic } \\
\text { facilities }\end{array}$ & $\begin{array}{c}\mathrm{F} \\
(3,5,7)\end{array}$ & $\begin{array}{l}\text { Perfect } \\
\text { Comparatively perfect } \\
\text { Regular } \\
\text { Poor } \\
\text { Little or none }\end{array}$ & $\begin{array}{c}\mathrm{VH} \\
\mathrm{H} \\
\mathrm{F} \\
\mathrm{L} \\
\mathrm{VL}\end{array}$ \\
\hline \multirow[t]{2}{*}{ Human factor $\left(C_{3}\right)$} & \multirow{2}{*}{$\begin{array}{c}\mathrm{VL} \\
(1,3,5)\end{array}$} & $\begin{array}{l}\text { Professional } \\
\text { quality }\end{array}$ & $\begin{array}{c}\mathrm{F} \\
(3,5,7)\end{array}$ & $\begin{array}{l}\text { Extreme specialized } \\
\text { Specialized } \\
\text { Slightly specialized } \\
\text { Sparsely specialized } \\
\text { Little or none }\end{array}$ & $\begin{array}{c}\mathrm{VH} \\
\mathrm{H} \\
\mathrm{F} \\
\mathrm{L} \\
\mathrm{VL}\end{array}$ \\
\hline & & $\begin{array}{l}\text { Working } \\
\text { enthusiasm }\end{array}$ & $\begin{array}{c}\mathrm{F} \\
(3,5,7)\end{array}$ & $\begin{array}{l}\text { Very high } \\
\text { High } \\
\text { Fair } \\
\text { Lower } \\
\text { Little or none } \\
\end{array}$ & $\begin{array}{c}\mathrm{VH} \\
\mathrm{H} \\
\mathrm{F} \\
\mathrm{L} \\
\mathrm{VL}\end{array}$ \\
\hline
\end{tabular}

Where: $\mathrm{VH}=(7,9,9) ; \mathrm{H}=(5,7,9) ; \mathrm{F}=(3,5,7) ; \mathrm{L}=(1,3,5) ; \mathrm{VL}=(1,1,3)$

performance of the approach. Each of these criteria and the overall performance of the above-mentioned model were rated in a range between good and very good. This demonstrates the effectiveness and practicability of the method.

Results show the performance of the Ningde geopark is overestimated, whereas behavior of the Huangshan geopark is underestimated compared to traditional synthetic index analysis (Fig. $3)$. The geoscience education level of Ningde geopark is relatively low because it has been lacks of basic infrastructure including the primary place for geoscience popularization, geomuseum, and associated supporting facilities. But in recent years the importance of geoscience popularization has been enhanced by promoting the in- depth scientific research, popularization activities and typical geoscience products. While in Huangshan Geopark, more attention had been paid to the development of the local economy and recent improvement of tourism image. Moreover, the results for these geoparks using the synthetic index method are inconsistent with the intuitive visual indication and ranking of the variation in the reliability of the considered data. The fuzzy multi-attribute method presented here can minimize subjectivity in appraisal of all controlling attributes to geoscience popularization variation, while optimizing flexibility to consider additional factors that influence vulnerability.

Inevitably, the accuracy and reliability of assessment results are greatly affected by data availability, data processing, weighting factors, 
Table 4. Linguistic assessment of alternatives for the geoparks

\begin{tabular}{|c|c|c|c|c|c|c|c|c|c|c|}
\hline $\begin{array}{l}\text { Sub- } \\
\text { attribute }\end{array}$ & Geopark name & $C_{11}$ & $C_{12}$ & $C_{13}$ & $C_{14}$ & $C_{15}$ & $C_{21}$ & $C_{22}$ & $C_{31}$ & $C_{32}$ \\
\hline$A_{1}$ & Wudalianchi Geopark & $\mathrm{L}$ & $\mathrm{L}$ & $\mathrm{L}$ & VL & VL & $\mathrm{L}$ & $\mathrm{L}$ & VL & $\mathrm{VL}$ \\
\hline$A_{2}$ & Jingbohu Geopark & $\mathrm{L}$ & VL & VL & VL & VL & $\mathrm{L}$ & $\mathrm{L}$ & $\mathrm{L}$ & VL \\
\hline$A_{3}$ & Fangshan Geopark & $\mathrm{F}$ & $\mathrm{H}$ & $\mathrm{F}$ & $\mathrm{F}$ & $\mathrm{F}$ & $\mathrm{VH}$ & $\mathrm{F}$ & $\mathrm{L}$ & $\mathrm{L}$ \\
\hline$A_{4}$ & Taishan Geopark & $\mathrm{L}$ & $\mathrm{L}$ & $\mathrm{L}$ & $\mathrm{L}$ & VL & VL & $\mathrm{F}$ & $\mathrm{L}$ & VL \\
\hline$A_{5}^{4}$ & Songshan Geopark & VL & VL & VL & VL & VL & $\mathrm{L}$ & $\mathrm{L}$ & VL & VL \\
\hline$A_{6}$ & Yuntaishan Geopark & $\mathrm{F}$ & $\mathrm{L}$ & F & $\mathrm{L}$ & $\mathrm{F}$ & $\mathrm{F}$ & $\mathrm{L}$ & $\mathrm{L}$ & VL \\
\hline$A_{7}$ & Wangwushan-Daimeishan Geopark & $\mathrm{F}$ & $\mathrm{F}$ & $\mathrm{F}$ & $\mathrm{F}$ & $\mathrm{F}$ & $\mathrm{F}$ & $\mathrm{F}$ & $\mathrm{L}$ & $\mathrm{L}$ \\
\hline$A_{s}$ & Funiushan Geopark & VL & VL & $\mathrm{VL}$ & VL & VL & VL & VL & VL & $\mathrm{VL}$ \\
\hline$A_{9}$ & Qinling-Zhongnanshan Geopark & $\mathrm{L}$ & $\mathrm{L}$ & VL & VL & VL & $\mathrm{L}$ & $\mathrm{L}$ & VL & VL \\
\hline$A_{10}$ & Yandangshan Geopark & $\mathrm{F}$ & $\mathrm{H}$ & $\mathrm{F}$ & $\mathrm{F}$ & $\mathrm{H}$ & $\mathrm{F}$ & $\mathrm{F}$ & $\mathrm{L}$ & $\mathrm{L}$ \\
\hline$A_{1}$ & Huangshan Geopark & $\mathrm{L}$ & VL & VL & VL & VL & $\mathrm{L}$ & $\mathrm{L}$ & $\mathrm{L}$ & $\mathrm{VL}$ \\
\hline$A_{12}$ & Tianzhushan Geopark & VL & VL & VL & VL & VL & $\mathrm{L}$ & $\mathrm{L}$ & VL & VL \\
\hline$A_{13}$ & Zhangjiajie Geopark & $\mathrm{L}$ & $\mathrm{L}$ & $\mathrm{L}$ & $\mathrm{L}$ & $\mathrm{L}$ & $\mathrm{L}$ & $\mathrm{L}$ & $\mathrm{L}$ & VL \\
\hline$A_{14}$ & Zigong Geopark & $\mathrm{F}$ & $\mathrm{H}$ & $\mathrm{F}$ & $\mathrm{F}$ & $\mathrm{H}$ & $\mathrm{F}$ & $\mathrm{F}$ & $\mathrm{L}$ & $\mathrm{L}$ \\
\hline$A_{15}^{14}$ & Xingwen Geopark & $\mathrm{L}$ & $\mathrm{L}$ & $\mathrm{L}$ & $\mathrm{L}$ & $\mathrm{L}$ & F & $\mathrm{L}$ & $\mathrm{L}$ & $\mathrm{L}$ \\
\hline$A_{16}$ & Lushan Geopark & VL & VL & VL & VL & VL & VL & VL & VL & VL \\
\hline$A_{17}$ & Longhushan Geopark & $\mathrm{L}$ & $\mathrm{L}$ & $\mathrm{L}$ & $\mathrm{L}$ & $\mathrm{L}$ & $\mathrm{L}$ & VL & VL & VL \\
\hline$A_{18}$ & Sanqingshan Geopark & $\mathrm{F}$ & $\mathrm{H}$ & F & $\mathrm{F}$ & $\mathrm{F}$ & F & $\mathrm{F}$ & $\mathrm{L}$ & $\mathrm{L}$ \\
\hline$A_{19}$ & Taining Geopark & VL & VL & VL & VL & VL & $\mathrm{L}$ & $\mathrm{L}$ & VL & VL \\
\hline$A_{20}$ & Ningde Geopark & $\mathrm{F}$ & $\mathrm{L}$ & $\mathrm{L}$ & $\mathrm{L}$ & $\mathrm{L}$ & $\mathrm{L}$ & $\mathrm{L}$ & $\mathrm{L}$ & VL \\
\hline$A_{21}$ & Leye-Fengshan Geopark & $\mathrm{F}$ & $\mathrm{H}$ & $\mathrm{F}$ & $\mathrm{F}$ & $\mathrm{L}$ & $\mathrm{F}$ & $\mathrm{F}$ & $\mathrm{L}$ & $\mathrm{L}$ \\
\hline$A_{22}$ & Danxiashan Geopark & $\mathrm{F}$ & $\mathrm{L}$ & $\mathrm{L}$ & $\mathrm{L}$ & $\mathrm{L}$ & $\mathrm{L}$ & $\mathrm{L}$ & $\mathrm{L}$ & VL \\
\hline$A_{23}$ & Leiqiong Geopark & $\mathrm{F}$ & $\mathrm{L}$ & $\mathrm{F}$ & $\mathrm{L}$ & $\mathrm{L}$ & $\mathrm{L}$ & $\mathrm{L}$ & $\mathrm{L}$ & $\mathrm{L}$ \\
\hline$A_{24}$ & Shiling Geopark & $\mathrm{F}$ & $\mathrm{H}$ & F & $\mathrm{F}$ & $\mathrm{L}$ & $\mathrm{F}$ & $\mathrm{F}$ & $\mathrm{L}$ & $\mathrm{L}$ \\
\hline$A_{25}^{24}$ & Hexigten Geopark & $\mathrm{F}$ & $\mathrm{L}$ & $\mathrm{F}$ & $\mathrm{L}$ & $\mathrm{F}$ & F & $\mathrm{F}$ & $\mathrm{L}$ & $\mathrm{L}$ \\
\hline$A_{26}^{20}$ & Alxa Desert Geopark & $\mathrm{F}$ & $\mathrm{L}$ & $\mathrm{L}$ & $\mathrm{L}$ & $\mathrm{L}$ & $\mathrm{L}$ & $\mathrm{L}$ & $\mathrm{L}$ & $\mathrm{L}$ \\
\hline$A_{27}^{26}$ & Hong Kong Geopark & $\mathrm{VH}$ & $\mathrm{VH}$ & $\mathrm{VH}$ & $\mathrm{VH}$ & $\mathrm{VH}$ & $\mathrm{H}$ & $\mathrm{H}$ & $\mathrm{VH}$ & $\mathrm{H}$ \\
\hline
\end{tabular}

and associated indices. The fuzzy multiattribute assessment method, however, provides a simple computational process that enables more rational estimation of geoscience education pattern by incorporating dominant factors and inherent uncertainty into an integrated set of analytical procedures. It produces a more reasonable rank order for vulnerability assessment, as shown in Table 5 and Fig. 3(A). Given the agreement with intuitive ranking schemes, the approach developed here is considered to provide a more rigorous, less subjective approach to decision-making.

\section{Discussion of geoscience popularization ranking}

The fuzzy multi-attribute estimation is effective in evaluating complex, subjective, and uncertain assessment problems (Deng and Yang, 2005). It generates meaningful and usable outputs that reveal the variation in the intensity of the considered data. The representative geopark with the highest level of geoscience popularization is Hong Kong Geopark (Wu and Fu, 2009; Yang et al., 2013; Fig. 3), where with diverse popularization ways and successful science

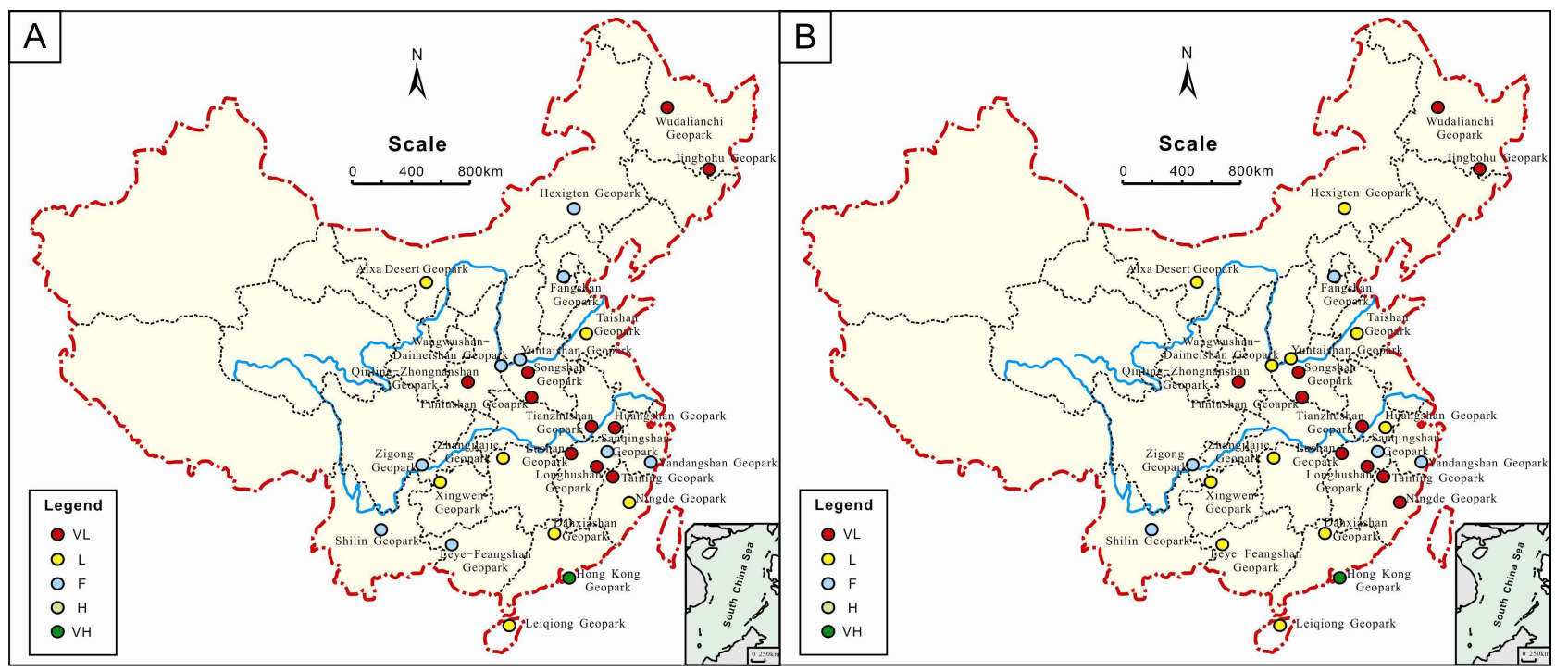

Figure 3. Assessment ranking for geoscience popularization within geoparks. $V H$ is very high, $H$ is high, $F$ is fair, $L$ is low, VL is very low. A refers to results from fuzzy multiattribute assessment approach (FMA); B refers to results from the synthetic index analysis (SIA). 
Table 5 Ranking of alternatives based on closeness coefficients and synthetic index analysis

\begin{tabular}{|c|c|c|c|c|}
\hline $\begin{array}{l}\text { Alter- } \\
\text { natives }\end{array}$ & $\begin{array}{c}\text { Closeness } \\
\text { coefficient }\left(P_{i}\right)\end{array}$ & $\begin{array}{c}\text { Ranking based } \\
\text { on FMA }\end{array}$ & Grade & $\begin{array}{l}\text { Results } \\
\text { from SIA }\end{array}$ \\
\hline$A_{1}$ & 0.241 & 18 & $\mathrm{VL}$ & VL \\
\hline$A_{2}$ & 0.238 & 20 & $\mathrm{VL}$ & $\mathrm{VL}$ \\
\hline$A_{3}$ & 0.396 & 2 & $\mathrm{~F}$ & $\mathrm{~F}$ \\
\hline$A_{4}$ & 0.260 & 17 & $\mathrm{~L}$ & $\mathrm{~L}$ \\
\hline$A_{5}$ & 0.213 & 25 & VL & VL \\
\hline$A_{6}$ & 0.319 & 10 & $\mathrm{~F}$ & $\mathrm{~L}$ \\
\hline$A_{7}$ & 0.365 & 8 & F & $\mathrm{L}$ \\
\hline$A_{8}$ & 0.172 & 27 & $\mathrm{VL}$ & $\mathrm{VL}$ \\
\hline$A_{9}$ & 0.231 & 22 & $\mathrm{VL}$ & $\mathrm{VL}$ \\
\hline$A_{10}$ & 0.380 & 4 & $\mathrm{~F}$ & F \\
\hline$A_{11}$ & 0.238 & 19 & VL & $\mathrm{L}$ \\
\hline$A_{12}$ & 0.213 & 24 & $\mathrm{VL}$ & VL \\
\hline$A_{13}$ & 0.272 & 16 & $\mathrm{~L}$ & $\mathrm{~L}$ \\
\hline$A_{14}$ & 0.380 & 3 & F & F \\
\hline$A_{15}$ & 0.307 & 11 & $\mathrm{~L}$ & $\mathrm{~L}$ \\
\hline$A_{16}$ & 0.172 & 26 & $\mathrm{VL}$ & VL \\
\hline$A_{17}$ & 0.233 & 21 & VL & $\mathrm{VL}$ \\
\hline$A_{18}$ & 0.374 & 5 & $\mathrm{~F}$ & F \\
\hline$A_{19}$ & 0.213 & 23 & $\mathrm{VL}$ & VL \\
\hline$A_{20}$ & 0.282 & 15 & $\mathrm{~L}$ & VL \\
\hline$A_{21}$ & 0.368 & 6 & F & $\mathrm{L}$ \\
\hline$A_{22}$ & 0.282 & 14 & $\mathrm{~L}$ & $\mathrm{~L}$ \\
\hline$A_{23}$ & 0.306 & 12 & $\mathrm{~L}$ & $\mathrm{~L}$ \\
\hline$A_{24}$ & 0.368 & 7 & F & F \\
\hline$A_{25}$ & 0.348 & 9 & $\mathrm{~F}$ & $\mathrm{~L}$ \\
\hline$A_{26}$ & 0.297 & 13 & $\mathrm{~L}$ & $\mathrm{~L}$ \\
\hline$A_{27}^{20}$ & 0.497 & 1 & VH & $\mathrm{VH}$ \\
\hline
\end{tabular}

popularization pattern being dominant. A large variety of popularization publications, excellent geoscience facilities, professional geoscience training, innovative awareness of geoscience popularization, as well as the detailed regional geology descriptions, reflects the novel way for geological information transmission. Geoparks of medium popularization levels are shown in blue on Fig. 3(A). These geoparks, characterized by paleontological resources, mostly own better scientific interpretation system and very good popularization infrastructure. The feasible geoscience publicity conditions increase popularization level in these geoparks (Chen, 2003; Huang and Yang, 2011; Yang et al., 2013). The geoparks with low and very low popularization level are principally along the middlelower Yangtze/Yellow River or located in the southeast China, as well as several geoparks in Heilongjiang and Inner Mongolia, as shown in yellow and red on Fig. 3. These areas are typically characterized by moderate-poor geoscience popularization museums and imperfect interpretation system (Huang and Yang, 2011; Yang et al., 2013). The lower intensity popularization products and already accelerated tourism activities limit the extent and strengthening of geoscience education in these geoparks. Although these were areas of active scenic spots, their education function has been gradually enhancing.

Disagreement between the synthetic index ranking procedures and the fuzzy multiattribute assessment method occurred in a few geoparks (Fig. 3). The Huangshan Geopark is considered to be vulnerable area because of the large numbers and variety of tourism activities and absence of local typical popularization products and materials. The fuzzy multiattribute assessment method, based on a rational ranking of estimation, provides a useful guide to geoscience popularization identification, thereby enhancing assessment for individual geoparks.

\section{Implications for prioritization of geoscience opularization issues within geoparks}

Fuzzy multiattribute assessment provides a scientific base for policy making relating to geoheritage utilization and geoscience popularization development. The method classifies the geoscience education levels of geoparks to software, hardware, and anthropogenic controlling, enabling inclusion of a range of variables without the need to depend upon arbitrary weightings. It is of great practical value to analyze the performance of geoscience popularization and the primary causes leading to these regional variations. In addition, this method highlights the importance of fuzzy multiattribute estimation for vague grading boundaries with respect to some sub-attributes. The application of fuzzy multiattribute method provides a helpful and practicable visual indication of the variation in the intensity of the given data. The method developed here generates estimates that correlate well with those attained through the use of an existing comprehensive index, indicating the priority geoparks where policy intervention is most needed.

Results from this study can be used to guide and prioritize management countermeasures to improve geoscience popularization in geoparks. Geoparks having lower popularization level should receive higher priority for appropriate regulations and methods to address geoscience education. Practical measures include increasing geomuseums and popularization centers to enlarge the education dynamics and coverage and establishing popularization management in these geoparks. Thus, impacts of anthropogenic qualities can be minimized in areas of low popularization potential. In moderately vulnerable popularization geoparks, integrated professional management should frame sustainable use of geological resources in relation to permanent development of the local economy. Modern popularization techniques and patterns can be applied to sustain geoscience transmission in these geoparks with fair popularization vulnerability. Comprehensive practices should link effective geoscience popularization/geoheritage protection with efforts to develop the regional economy. Results from this study imply that future policy-making in different geoparks should be targeted in regions with higher popularization performance. Based on these insights, future management practices can effectively balance geoscience popularization while promoting regional sustainable development.

\section{Conclusion}

Vulnerability assessment of geoscience popularization with 27 global geoparks in China is a complex problem that involves subjective assessments and multiple attributes. This paper applies a fuzzy multiattribute approach to vulnerability assessment. The approach incorporates the dominant factors in an integrated analysis, thereby eliciting and producing a more reasonable ranking order of factors that affect popularization performance in the geoparks in relation to internal and external factors. This analysis enables inclusion of various variables without the need to depend upon arbitrary weightings. The subjective and vague information for subattribute grading can be properly handled in the fuzzy multiple attribute estimation. Additionally, the fuzzy multi-attribute method presented in this paper 
highlights the relevant data that can be easily acquired and used by planners and decision makers. As a local level, this analysis provides managers with an effective methodology and analytical tool for identifying those geoparks at different popularization levels. Results of this study indicate that the degree of popularization in the study area is largely determined by hardware and software in relation to geoscience popularization, with overall performance slightly adjusted by human factors. The consistency of the results between the fuzzy assessment approach and traditional index analysis indicates that the approach to popularization assessment is rational and the computational requirements are not burdensome. Results of the study can be used to guide geoheritage exploitation and geoscience popularization improvement, aiding efforts to support the sustainable development of the geopark.

\section{Acknowledgements}

This study was supported in part by National Natural Science Foundations of China (No. 41320003, 41002036, 41172167, G.F. Yang; No. 41220001, Zhenghong Chen), and was undertaken as part of the Fundamental Research Funds for the Central Universities (No. 2011YYL129, G.F. Yang). This work was also a contribution to Funding from the China Association for Science and Technology (No. 2012KPYJ03-2, G.F. Yang), within which a research team from China University of Geosciences, Beijing and China Meteorological Administration Training Centre is studying the periodical characters of geoscience popularization within world geoparks of China and their possible implications. We greatly appreciate the detailed and thoughtful comments of the two reviewers, particularly the time and care taken by Dr. Robert A. L. Wray.

\section{References}

Chen, A.Z., 2002, A survey of national Geopark. Proceedings of Feitianshan Danxia Landform and Eco-tourism Symposium, pp. 15-26. (in Chinese)

Chen, A.Z., 2003, Some problems about the construction of national geoparks in China. Resources \& Industries v. 5, pp. 58-64. (in Chinese)

Chen, C., Klein, C.M., 1997, An efficient approach to solving fuzzy MADM problems. Fuzzy Sets and Systems v. 88, pp. 51-67.

Chen, C-T., 2000, Extensions of the TOPSIS for group decision-making under fuzzy environment. Fuzzy Sets and Systems v. 114, pp. 1-9.

Comãnescu, L., Nedelea, A., 2012, The assessment of geodiversity-a premise for declaring the geopark Buzãului County (Romania). J. Earth Syst. Sci. v. 121, pp. 1493-1500.

Deng, H.P., Yang, G.F., 2005, A fuzzy multicriteria analysis approach to the optimal use of reserved land for agriculture. Lecture Notes in Computer Science v. 3613, pp. 653-661.

Eder, F.W., Patzak, M., 2004, Geoparks_-geological attractions: A tool for public education, recreation and sustainable economic development. Episodes v. 25, pp. 162-164.

Huang, J.W., Yang, Q.J., 2011, Review on the situation of the networkedpopularization of science in global geopark of China. Journal of Ningxia Teachers University (Natural Science) v. 32, No. 6, 74-81. (in Chinese)

Qian, F., Ling, X.H., 2005, Comparison study of American National Parks and Chinese National Geoparks. Proceedings of 19th Annual Meeting of Tourism Geology. (in Chinese, unpublished)

Qian, X.M., Zhao, Y., 2004, The development construction of world geoparks and their reference to China. World Geographic Research v. 13, No. 4, pp. 83-84. (in Chinese)

Rashed, T., Weeks, J., 2003, Assessing vulnerability to earthquake hazards through spatial multicriteria analysis of urban areas. International Journal of Geographic Information Science v. 17, pp. 547-576.

Serrano, E., Ruiz Flano, P., 2007, Geodiversity: A theoretical and applied concept. Geographica Helvetica v. 62, No. 4, pp. 140-147.

UNESCO, 2008, Operational Guidelines for the Implementation of the World Heritage convention.

Wu, M., Fu, G.L., 2009, Effect of popular science propaganda on geoparks' construction and development. Resource and Industries v. 11, No. 1, pp. 61-62. (in Chinese)

Yang, G.F., Chen, Z.H., Li, Y.L., 2013, Scientific Report of Science Popularization and Education Countermeasures within Natural Reserve, Geoparks, Zoo-Botanical Gardens of China, pp. 1-82. (in Chinese, Interior report, unpublished)

Yang, G.F., Chen, Z.H., Tian, M.Z., Wu, F.D., Wray, R.A.L., Ping, Y.M., 2011, On the growth of national geoparks in China: distribution, interpretation, and regional comparison. Episodes v. 34, No. 3, pp. 157-176.

Zhao, X., Wang, M., 2002, National geoparks initiated in China: putting geoscience in the service of society. Episodes v. 25, No. 1, pp. 33-37.

Zouros, N., Valiakos, I., 2010, Geoparks management and assessment. Bulletin of the Geological Society of Greece, v. XLIII, No. 2, pp. 965-975. 